\title{
Effects of milk replacer feeding levels on performance and metabolism of preweaned dairy calves during summer
}

\author{
R. M. Orellana Rivas, G. H. Komori, V. V. Beihling, T. N. Marins, J. K. Bernard, and S. Tao* \\ Department of Animal and Dairy Science, University of Georgia, Tifton 31793
}

\section{ABSTRACT}

The objective of this study was to evaluate the effect of milk replacer (MR) feeding programs on performance and metabolism during summer. At $3 \mathrm{~d}$ of age (DOA), calves were randomly assigned to 1 of 4 dietary treatments: control [CON; $0.55 \mathrm{~kg}$ dry matter (DM) of a $20 \%$ crude protein (CP) and $20 \%$ fat MR per day], intermediate (IL; $0.66 \mathrm{~kg} \mathrm{DM}$ of a $26 \% \mathrm{CP}$ and $17 \%$ fat MR per day), high (HL; $0.77 \mathrm{~kg}$ DM of a $26 \% \mathrm{CP}$ and $17 \%$ fat MR per day), or aggressive (AL; $0.87 \mathrm{~kg} \mathrm{DM}$ of a $26 \% \mathrm{CP}$ and $17 \%$ fat MR per day). Calves were managed similarly and housed in individual polyethylene hutches using sand as a bedding material. Because 3 calves fed the AL diet developed abomasum bloating during the first $30 \mathrm{DOA}$, the AL treatment was terminated. Milk replacer (12.5\% solids) was offered twice daily until $42 \mathrm{DOA}$, when MR was fed once daily to reduce its intake by $50 \%$. Calves were weaned at 49 DOA and remained in hutches until 56 DOA. Calf starter and water were offered ad libitum. Ambient temperature and relative humidity in and outside the hutches were assessed hourly. Starter and MR intakes were recorded daily. Respiration rate and rectal temperature were determined 3 times each week. Body weight was measured at $3,14,28,42$, and 56 DOA. Plasma was collected at 5, 10, 14, 28, 42, 43, 45, 47, 49, 51, and 56 DOA for analysis of glucose, $\beta$-hydroxybutyrate, triglycerides, nonesterified fatty acids, urea nitrogen, and insulin concentrations. There were no treatment effects on starter intake, rectal temperature, or respiration rate. By $7 \mathrm{DOA}$, calves fed the IL and HL diets consumed the same amount of MR and a higher amount of MR than the CON calves. At wk 2, calves from all treatments had similar MR consumption before returning to the projected intake by design at wk 4. Calves fed the IL and HL treatments had similar body weight but were heavier than those fed the CON diet at wk 6, 7, and 8. Calves fed the IL

Received July 30, 2019.

Accepted September 14, 2019.

*Corresponding author: stao@uga.edu and HL diets had similar average daily gain, which was higher than that of calves fed the CON diet. There was no difference in plasma metabolites among treatments, but insulin concentration increased as milk allowance increased. In summary, feeding an intermediate level of MR during summer improved calf growth compared with the CON diet, but a higher MR allowance did not support further improvements in calf performance.

Key words: milk allowance, preweaned calf, heat stress

\section{INTRODUCTION}

Environment influences animals' performance, health, and related nutritional management. Compared with calves under temperate conditions, preweaned calves raised during summer have reduced ADG (Wiedmeier et al., 2006; Broucek et al., 2009; Chavez, 2011). Reasons for the poor performance of calves during summer are multifactorial and include pre- and postnatal heat stress, increased fly density, and wetter bedding due to increased rainfall (Broucek et al., 2009; Monteiro et al., 2016). Among these factors, the major factor limiting calf growth may be postnatal heat stress. Similar to mature cows, preweaned calves have increased body temperature and respiration rate when raised in an environment with elevated ambient temperatures (Gebremedhin et al., 1981; Hill et al., 2016a). The respiratory and cutaneous evaporative cooling of the calf is initiated when ambient temperature exceeds $20^{\circ} \mathrm{C}$ (Gebremedhin et al., 1981), above which energy utilization for cooling increases at the expense of other functions. This redistribution of energy increases energy required for maintenance and consequently reduces energy available for growth (Gebremedhin et al., 1981). Further, preweaned calves have decreased starter intake when exposed to summer conditions compared with those under thermoneutrality (Chavez, 2011). Reduced total energy intake results from lower starter intake, which, combined with the increase in energy cost for maintenance, decreases net energy available for growth. Consequently, preweaned calves raised during summer have lower ADG compared with those raised in cooled 
or temperate environments (Wiedmeier et al., 2006; Broucek et al., 2009). The stunted animal growth during summer may also lower future productivity. Soberon et al. (2012) reported that ADG during the preweaning period was positively correlated with a heifer's milk yield in first lactation. Reduced energy and nutrient consumption has implications for calf immunity and disease resistance as well. Compared with preweaned calves fed a low plane of nutrition of milk replacer (MR), calves fed a higher plane of nutrition had lower blood neutrophil activity before weaning (Obeidat et al., 2013; Ballou et al., 2015) but displayed stronger resistance to disease challenges during the postweaning period (Ballou et al., 2015; Sharon et al., 2019). Thus, management and nutrition strategies need to be developed to improve performance of calves raised during summer.

Management approaches, such as providing forced ventilation, have proven effective at improving calf growth in summer (Hill et al., 2011). However, cooling alone cannot completely abate heat stress. The diversity of calf housing options in the dairy industry also limits the utilization of heat abatement to improve growth. A recent national survey indicated that $37.9 \%$ of dairy operations in western and eastern regions of the United States used individual outside hutches to house preweaned calves (USDA-NAHMS, 2016), where forced ventilation is not effective. Similarly, individual hutches are the predominant housing option for preweaned calves in the southeastern region of the United States. Thus, additional nutrition strategies need to be developed to enhance calf growth during summer. Due to the higher energy requirement for maintenance and lower calf starter intake caused by heat stress, it is logical to hypothesize that increasing the quantity of MR fed to calves during summer would increase the dietary energy available for growth, thereby enhancing ADG. Hill et al. (2012) reported that increasing the feeding level of a traditional MR containing $20 \% \mathrm{CP}$ and $20 \%$ fat (20:20, as fed basis) from 0.44 to $0.55 \mathrm{~kg}$ of DM/d during summer improved the ADG of preweaned calves without influencing calf starter intake. However, similar results were not observed during winter (Hill et al., 2012), suggesting that feeding more traditional MR to preweaned calves may improve animal growth in summer. Relative to the traditional 20:20 MR feeding regimen $(0.44-0.55 \mathrm{~kg} / \mathrm{d})$, accelerated feeding programs that entail feeding large quantities of MR containing higher protein content have gained popularity due to the higher ADG of preweaned calves raised on this feed regimen (Khan et al., 2007). However, it is unknown whether increasing the feeding rate in an accelerated MR program during summer could improve calf growth.
Therefore, our hypothesis was that increasing the MR allowance of preweaned calves during summer would improve growth. The objective was to examine the effect of $4 \mathrm{MR}$ feeding rates on calf growth performance and blood metabolites and insulin during summer.

\section{MATERIALS AND METHODS}

\section{Animals and Experimental Design}

The University of Georgia Institutional Animal Care and Use Committee approved the procedures and animal handling before trial initiation. The study was conducted at the Dairy Research Center of the University of Georgia-Tifton campus from June to October 2016. A total of 52 calves were enrolled in the experiment. Within $6 \mathrm{~h}$ after calving, calves were removed from their dam and fed $940 \mathrm{~g}$ of colostrum replacer containing at least $200 \mathrm{~g}$ of $\mathrm{IgG}$ (bovine IgG colostrum replacer; Land O'Lakes Inc., Arden Hills, MN). The day of birth was considered $1 \mathrm{~d}$ of age (DOA).

At $2 \mathrm{DOA}$, calves were fed $0.55 \mathrm{~kg} / \mathrm{d}$ (DM basis) of a 20:20 MR (Provimi North America Inc., Brookville, $\mathrm{OH})$ twice daily $(0700$ and $1600 \mathrm{~h})$. At $3 \mathrm{DOA}$, calves were weighed and randomly assigned by sex and calving date to 1 of the 4 feeding programs: control $[\mathbf{C O N} ; \mathrm{n}=$ 14 ( 8 heifers, 6 bulls); $0.55 \mathrm{~kg}$ DM of 20:20 MR (Provimi North America Inc.) per day], intermediate [IL; $\mathrm{n}=13$ (7 heifers, 6 bulls); $0.66 \mathrm{~kg} \mathrm{DM}$ of $26 \% \mathrm{CP}$ and $17 \%$ fat (as-fed basis; 26:17) MR (Provimi North America Inc.) per day], high [HL; $\mathrm{n}=13$ (6 heifers, 7 bulls); $0.77 \mathrm{~kg}$ DM of $26: 17 \mathrm{MR}$ per day], and aggressive [AL; $\mathrm{n}=12$ (6 heifers, 6 bulls); $0.87 \mathrm{~kg}$ DM of 26:17 MR per day]. Both MR products were medicated with lasalocid and comprised the same ingredients, including dried whey, dried milk protein, whey protein concentrate, dry skim milk, and vegetable and animal fat. Three calves fed the AL diet developed abomasal bloating at 10, 10, and 29 DOA, and 2 died. No abomasal bloating was observed in other treatments. Consequently, the AL treatment was terminated. All calves were managed similarly and housed in individual polyethylene hutches without shade. During the experiment, the door of the hutches was oriented to the east, and the windows in the back and on the ridge of the hutch were opened for ventilation. Sand was used as the bedding material and was cleaned twice each day and replaced once weekly.

\section{Feeding, Intake, and Growth Measures}

Milk replacer was reconstituted with warm water to $12.5 \%$ solids and offered to calves twice daily at 0700 and $1600 \mathrm{~h}$. Equal amounts were fed each feeding until 
42 DOA, when MR allowance was reduced $50 \%$ and fed once daily $(0700 \mathrm{~h})$. Calves were initially fed by bottles and were trained to drink from buckets at 4 DOA. Calves were weaned at $49 \mathrm{DOA}$ and remained in hutches until 56 DOA. The MR intake was calculated by subtracting the amount refused from the amount offered. Textured calf starter (Godfrey's Warehouse Inc., Madison, GA) was provided ad libitum starting at 2 DOA, and the intake was recorded daily. From 43 DOA, when the MR allowance was reduced, $227 \mathrm{mg}$ of a coccidiostat (amprolium, Corid 1.25\% Crumbles; Provimi North America Inc.) was supplemented daily until calves completed the experiment. Representative samples of MR and calf starter were collected once each week and pooled monthly for chemical analysis (Table 1) at Cumberland Valley Analytical Services (Waynesboro, PA). Water was offered ad libitum throughout the entire experiment. To evaluate the growth, BW, body length, withers height, heart girth, and hip height were measured at 3,14, 28, 42, and 56 DOA, approximately $3 \mathrm{~h}$ after morning feeding.

\section{Environment, Rectal Temperature, Respiration Rate, Fecal Scoring, and Scour Incidence}

The ambient temperature and relative humidity in and outside the hutch were measured every 15 min by Hobo Pro Series Temp probes (Onset Computer Corporation, Pocasset, MA) during the entire experiment.
For outside temperatures, a probe was hung on the fence adjacent to the hutches. A probe was hung in the middle of an empty hutch approximately $1 \mathrm{~m}$ above the ground to measure temperatures inside the hutch. Rectal temperature and respiration rate were assessed 3 times each week (Monday, Wednesday, and Friday) at $1430 \mathrm{~h}$. Rectal temperature was measured using a thermometer (20-s digital thermometer, 144-920-000, ReliOn; Mabis Healthcare Inc., Waukegan, IL), and respiration rate was assessed by counting flank movement for $1 \mathrm{~min}$. Fecal score was recorded twice daily (0730 and $1630 \mathrm{~h}$ ) throughout the experiment according to the calf health scoring chart developed by the School of Veterinary Medicine, University of Wisconsin-Madison (2011). A scouring calf was diagnosed based on the appearance of loose feces, reduced intake, and dehydration and was treated with 3 doses of ceftiofur sodium (Naxcel; Zoetis Services LLC, Parsippany, NY) and 1 dose of flunixin meglumine (Banamine; Merck Animal Health Intervet Inc., Madison, NJ). The MR allowance during the afternoon feeding was replaced with electrolyte (Re-Sorb; Zoetis Services LLC) for 3 to $5 \mathrm{~d}$ depending on whether the calf was recovered.

\section{Blood Sample Collection and Analyses}

Blood samples were collected via jugular venipuncture into sodium-heparinized Vacutainer tubes (Becton Dickinson, Franklin Lakes, NJ) at 5, 10, 14, 28, 42, 43,

Table 1. Nutrient content (mean \pm SD) of milk replacers (MR) containing either $20 \% \mathrm{CP}$ and $20 \%$ fat (as-fed basis; $20: 20$ ) or $26 \% \mathrm{CP}$ and $17 \%$ fat (as-fed basis; $26: 17$ ) and calf starter

\begin{tabular}{lccr}
\hline Item, \% of DM unless noted & $\begin{array}{c}20: 20 \mathrm{MR} \\
(\mathrm{n}=5)\end{array}$ & $\begin{array}{c}26: 17 \mathrm{MR} \\
(\mathrm{n}=5)\end{array}$ & $\begin{array}{c}\text { Calf starter } \\
(\mathrm{n}=5)\end{array}$ \\
\hline $\mathrm{DM}, \%$ & $95.68 \pm 0.84$ & $95.12 \pm 0.61$ & $87.20 \pm 2.28$ \\
$\mathrm{CP}$ & $20.50 \pm 0.66$ & $27.54 \pm 1.40$ & $18.64 \pm 1.45$ \\
Fat & $22.82 \pm 0.47$ & $18.68 \pm 1.33$ & $3.33 \pm 0.32$ \\
Lactose $^{1}$ & $50.55 \pm 0.62$ & $47.45 \pm 2.18$ & - \\
ADF & - & - & $12.46 \pm 0.50$ \\
Ash-free NDF & - & - & $22.16 \pm 1.16$ \\
NFC & $6.13 \pm 0.40$ & $6.33 \pm 0.52$ & $47.18 \pm 2.33$ \\
Ash & $4.90 \pm 0.03$ & $4.80 \pm 0.09$ & $2.84 \pm 1.40$ \\
ME, ${ }^{1} \mathrm{Mcal} / \mathrm{kg}$ of DM & $0.47 \pm 0.01$ & $0.53 \pm 0.06$ & $1.13 \pm 0.28$ \\
Calcium & $0.47 \pm 0.01$ & $0.54 \pm 0.03$ & $0.50 \pm 0.02$ \\
Phosphorus & $0.07 \pm 0.00$ & $0.08 \pm 0.01$ & $0.30 \pm 0.04$ \\
Magnesium & $1.41 \pm 0.05$ & $1.43 \pm 0.06$ & $1.68 \pm 0.09$ \\
Potassium & $0.46 \pm 0.02$ & $0.53 \pm 0.14$ & $0.28 \pm 0.12$ \\
Sodium & $333.98 \pm 6.98$ & $332.10 \pm 24.47$ & - \\
Osmolality, ${ }^{2}$ mOsm/kg & $70.00 \pm 25.77$ & $79.20 \pm 58.30$ & $249.80 \pm 22.22$ \\
Iron, mg/kg of DM & $33.80 \pm 12.68$ & $17.20 \pm 3.27$ & $96.00 \pm 17.51$ \\
Manganese, mg/kg of DM & $60.40 \pm 11.06$ & $28.40 \pm 14.12$ & $130.80 \pm 20.64$ \\
Zinc, mg/kg of DM & $12.00 \pm 7.38$ & $24.00 \pm 41.42$ & $20.40 \pm 2.07$ \\
Copper, mg/kg of DM & & &
\end{tabular}

${ }^{1}$ Calculated according to NRC (2001).

${ }^{2}$ Roughly estimated according to the following equation: osmolality, $\mathrm{mOsm} / \mathrm{kg}=[$ lactose, $\mathrm{mmol} / \mathrm{L}]+[$ sodium, $\mathrm{mmol} / \mathrm{L}]+[$ potassium, mmol/L $]+[$ magnesium, mmol/L $]+[$ calcium, mmol/L $]+[$ phosphorus, $\mathrm{mmol} / \mathrm{L}]$ (Constable et al., 2009; Wilms et al., 2019). 
$45,47,49,51$, and $56 \mathrm{DOA}$ at $1100 \mathrm{~h}$ and immediately placed on ice. Samples were centrifuged at 2,619 $\times g$ at $4^{\circ} \mathrm{C}$ for $30 \mathrm{~min}$ to collect plasma. Plasma concentrations of glucose (autokit glucose; Wako Chemicals USA Inc., Richmond, VA), nonesterified fatty acids [HR series NEFA-HR(2); Wako Chemicals USA Inc.], BHB (autokit 3-HB; Wako Chemicals USA Inc.), triglyceride (L-type triglyceride M; Wako Chemicals USA Inc.), urea nitrogen (urea nitrogen kit; Pointe Scientific Inc., Canton, MI), and insulin (bovine insulin ELISA; Mercodia AB, Uppsala, Sweden) were determined using commercially available kits; the inter- and intra-assay coefficients of variation were 9.5 and $4.2 \%, 5.8$ and $5.8 \%, 8.0$ and $3.6 \%, 16.7$ and $7.0 \%, 7.1$ and $6.7 \%$, and 13.5 and $3.7 \%$, respectively.

\section{Statistical Analyses}

Because the AL treatment was terminated, only data collected from calves enrolled in the CON, IL, and HL treatments were included in the statistical analyses. The UNIVARIATE procedure of SAS 9.4 (SAS Institute Inc., Cary, NC) was used to summarize the ambient temperature and relative humidity, and the means \pm standard deviation are reported. Repeated-measures data, including intake data (MR, starter, total DM, fat, $\mathrm{CP}, \mathrm{ME}$ ), BW, ADG, weekly fecal score, and plasma concentrations of metabolites and insulin, were analyzed using the MIXED procedure of SAS 9.4. The model included fixed effects of treatment, sex, time, and their interactions with calf (treatment) as the random effect, and the least squares means \pm standard error of the mean were reported. The incidence of scours was analyzed using the LOGISTIC procedure of SAS 9.4, and the day of the first incidence of scours was analyzed using the GLM procedure of SAS 9.4. The models included treatment and sex, and the least squares means \pm standard error of the mean were reported. Simple regression using the GLM procedure with the solution function of SAS 9.4 was used to determine the relationships between ADG and intakes from 3 to 49 DOA.

\section{RESULTS}

Nutrient contents of MR and calf starter are reported in Table 1. The CP and fat contents (\% of DM) for 20:20 MR, 26:17 MR, and calf starter were 20.5 and $22.8 \%, 27.5$ and $18.7 \%$, and 18.6 and $3.3 \%$, respectively. During the experiment, the average ambient temperature and relative humidity were $26.0 \pm 5.8^{\circ} \mathrm{C}$ (mean $\pm \mathrm{SD})$ and $75.2 \pm 19.9 \%$ inside the hutch and $25.4 \pm$ $4.0^{\circ} \mathrm{C}$ and $79.2 \pm 16.3 \%$ outside the hutch, respectively.

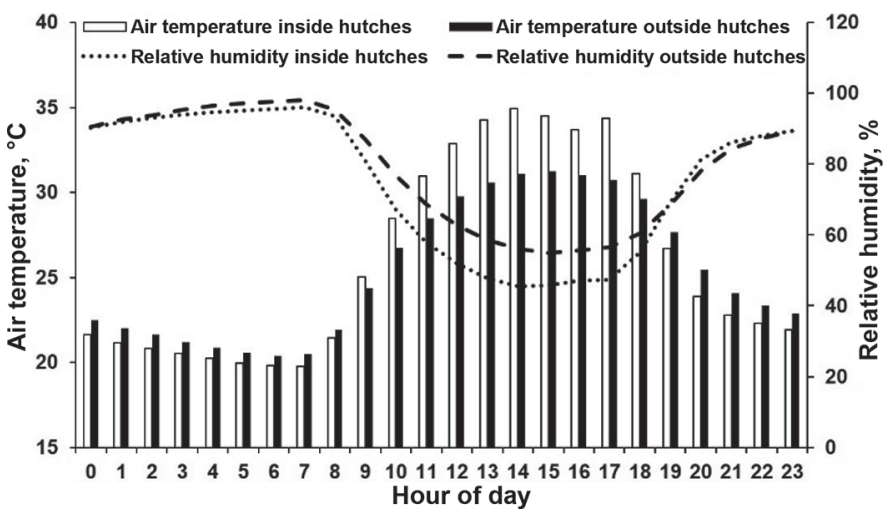

Figure 1. Ambient temperature and relative humidity inside and outside the hutches.

From 1000 to $1800 \mathrm{~h}$, the ambient temperature was higher but the relative humidity was lower inside the hutch than outside (Figure 1). Milk replacer feeding rates or treatment $\times$ time interaction had no $(P \geq$ $0.28)$ effect on rectal temperature or respiration rate of the calves (Table 2). However, treatment tended $(P \leq$ $0.10)$ to affect fecal score and the incidence of scours, as calves fed the HL diet had greater $(P \leq 0.05)$ fecal score during the first 4 wk of life and higher $(P \leq 0.05)$ incidence of scours compared with calves fed the CON diet; values for calves fed the IL diet were intermediate (Table 2).

There was a treatment $\times$ time interaction $(P<0.01)$ for MR intake (Table 3; Figure 2A). At wk 1 of age, calves fed the IL and HL diets consumed the same amount $(P=0.76)$ of $\mathrm{MR}$ and consumed a higher $(P$ $<0.01$ ) amount than calves fed the CON diet. At wk 2 , calves from all treatments had similar $(P \geq 0.18)$ MR consumption, mainly due to a higher occurrence of scours, when MR was replaced with electrolytes during the afternoon feeding. From wk 3 to 7 of age, calves fed the HL diet consumed more MR than calves fed the CON diet; values for calves fed the IL diet were intermediate $(P<0.01$; Figure 2A). Treatment or treatment $\times$ time interaction had no effect on calf starter intake or total DMI ( $P \geq 0.13$; Table 3$)$. However, there were treatment $\times$ time interactions $(P \leq 0.05)$ for intake of $\mathrm{CP}$, fat, and ME (Table 3; Figure 2). From wk 1 to 6 , intake of $\mathrm{CP}$ was similar $(P \geq 0.26)$ in calves fed the HL and IL diets and was higher $(P \leq 0.05)$ than that in calves fed the $\mathrm{CON}$ diet (Figure $2 \mathrm{~B}$ ). Fat intake was greater $(P=0.03)$ for CON calves compared with IL or HL calves at wk 2 of age. However, from wk 4 to 6 , calves fed the CON and IL diets had similar $(P \geq$ $0.62)$ fat intake, which was lower $(P \leq 0.01)$ than that observed for calves fed the HL diet (Figure 2C). From 
Table 2. Rectal temperature, respiration rate, fecal scores, incidence of scours, and the day of the first incidence of scour of calves fed experimental diets starting from d 3 of age ${ }^{1}$

\begin{tabular}{|c|c|c|c|c|c|c|c|}
\hline \multirow[b]{2}{*}{ Item } & \multicolumn{3}{|c|}{ Treatment $^{2}$} & \multirow[b]{2}{*}{ SEM } & \multicolumn{3}{|c|}{$P$-value } \\
\hline & $\mathrm{CON}$ & IL & HL & & Treatment & Time & $\begin{array}{l}\text { Treatment } \\
\quad \times \text { time }\end{array}$ \\
\hline Rectal temperature, ${ }^{\circ} \mathrm{C}$ & 39.63 & 39.55 & 39.64 & 0.06 & 0.58 & $<0.01$ & 0.50 \\
\hline Respiration rate, breaths/min & 73.39 & 74.11 & 76.51 & 1.96 & 0.51 & $<0.01$ & 0.28 \\
\hline Fecal score wk 1-4 & $0.69^{\mathrm{a}}$ & $0.87^{\mathrm{ab}}$ & $0.97^{\mathrm{b}}$ & 0.09 & 0.10 & $<0.01$ & 0.55 \\
\hline Fecal score wk 5-8 & 0.21 & 0.18 & 0.15 & 0.04 & 0.52 & 0.22 & 0.84 \\
\hline
\end{tabular}

${ }^{\mathrm{a}, \mathrm{b}}$ Means within a row with different superscripts differ $(P \leq 0.05)$.

${ }^{1}$ All calves were housed in individual polyethylene hutches during the summer and fed twice daily.

${ }^{2} \mathrm{CON}=0.55 \mathrm{~kg}$ DM of a $20 \% \mathrm{CP}$ and $20 \%$ fat milk replacer per day; $\mathrm{IL}=0.66 \mathrm{~kg} \mathrm{DM}$ of a $26 \% \mathrm{CP}$ and $17 \%$ fat milk replacer per day; $\mathrm{HL}=$ $0.77 \mathrm{~kg}$ DM of a $26 \% \mathrm{CP}$ and $17 \%$ fat milk replacer per day.

wk 3 to 6 of age, calves fed the HL diet consumed more $(P<0.05)$ ME compared with calves fed the CON diet; values for calves fed the IL diet were intermediate (Figure 2D).

There was no difference $(P=0.11)$ between treatments on BW, but calves fed the CON diet had lower $(P<0.01)$ BW compared with calves fed the HL and IL diets at 42, 49, and 56 DOA (treatment $\times$ time: $P<$ 0.01; Table 4; Figure 3). Compared with those fed the CON diet, calves fed the HL and IL diets had greater ADG $(P=0.05)$ and overall gain in BW, heart girth, and hip height $(P \leq 0.02)$ from 3 to $56 \mathrm{DOA}$, but no differences $(P>0.10)$ were observed between calves fed the HL and IL diets (Table 4). There were no differences between treatments in withers height gain from 3 to 56 DOA, but calves fed the IL and HL diets had greater $(P=0.05)$ withers height gain from 28 to 56 DOA compared with calves fed the CON diet (Table 4).

Milk replacer feeding rates had no $(P \geq 0.16)$ effect on ADG per kilogram of $\mathrm{CP}$ or fat intake. Compared with CON calves, calves fed the IL and HL diets had greater $(P \leq 0.05)$ ADG/DMI and ADG/ME intake, but no differences were observed between calves fed IL and HL (Table 3$)$. The ADG was correlated $(P<0.01)$ with total intake of $\mathrm{DM}, \mathrm{CP}$, fat, and $\mathrm{ME}$, and the coefficient of determination was $0.58,0.63,0.18$, and 0.69, respectively (Figure 4).

There were no differences $(P \geq 0.26)$ among treatment or interactions for plasma glucose, nonesterified fatty acids, BHB, and triglyceride. Plasma insulin concentrations were highest $(P<0.01)$ for HL, intermediate for IL, and lowest for CON (Table 5). A treatment

Table 3. Intake and efficiency of calves fed experimental diets starting from d 3 of age ${ }^{1}$

\begin{tabular}{|c|c|c|c|c|c|c|c|}
\hline \multirow[b]{2}{*}{ Item } & \multicolumn{3}{|c|}{ Treatment $^{2}$} & \multirow[b]{2}{*}{ SEM } & \multicolumn{3}{|c|}{$P$-value } \\
\hline & $\mathrm{CON}$ & IL & HL & & Treatment & Time & $\begin{array}{l}\text { Treatment } \\
\times \text { time }\end{array}$ \\
\hline Milk replacer, $\mathrm{kg} / \mathrm{d}$ & 0.466 & 0.555 & 0.615 & 0.010 & $<0.01$ & $<0.01$ & $<0.01$ \\
\hline Starter, $\mathrm{kg} / \mathrm{d}$ & 0.413 & 0.417 & 0.393 & 0.049 & 0.93 & $<0.01$ & 0.99 \\
\hline DMI, kg/d & 0.827 & 0.905 & 0.929 & 0.046 & 0.25 & $<0.01$ & 0.13 \\
\hline $\mathrm{CP}, \mathrm{kg} / \mathrm{d}$ & 0.162 & 0.212 & 0.221 & 0.010 & $<0.01$ & $<0.01$ & 0.05 \\
\hline Fat, $\mathrm{kg} / \mathrm{d}$ & 0.109 & 0.105 & 0.114 & 0.003 & 0.20 & $<0.01$ & $<0.01$ \\
\hline ME, Mcal/d & 3.199 & 3.527 & 3.687 & 0.152 & 0.07 & $<0.01$ & 0.01 \\
\hline ADG/DMI, $\mathrm{g} / \mathrm{g}$ & $0.338^{\mathrm{a}}$ & $0.441^{\mathrm{b}}$ & $0.446^{\mathrm{b}}$ & 0.030 & 0.02 & $<0.01$ & 0.78 \\
\hline $\mathrm{ADG} / \mathrm{CP}, \mathrm{g} / \mathrm{g}$ & 1.732 & 1.921 & 1.903 & 0.140 & 0.56 & $<0.01$ & 0.99 \\
\hline $\mathrm{ADG} / \mathrm{fat}, \mathrm{g} / \mathrm{g}$ & 4.345 & 5.646 & 5.389 & 0.504 & 0.16 & $<0.01$ & 0.77 \\
\hline $\mathrm{ADG} / \mathrm{ME}, \mathrm{g} / \mathrm{Mcal}$ & $92.2^{\mathrm{a}}$ & $117.4^{\mathrm{b}}$ & $115.5^{\mathrm{b}}$ & 8.3 & 0.05 & $<0.01$ & 0.92 \\
\hline
\end{tabular}




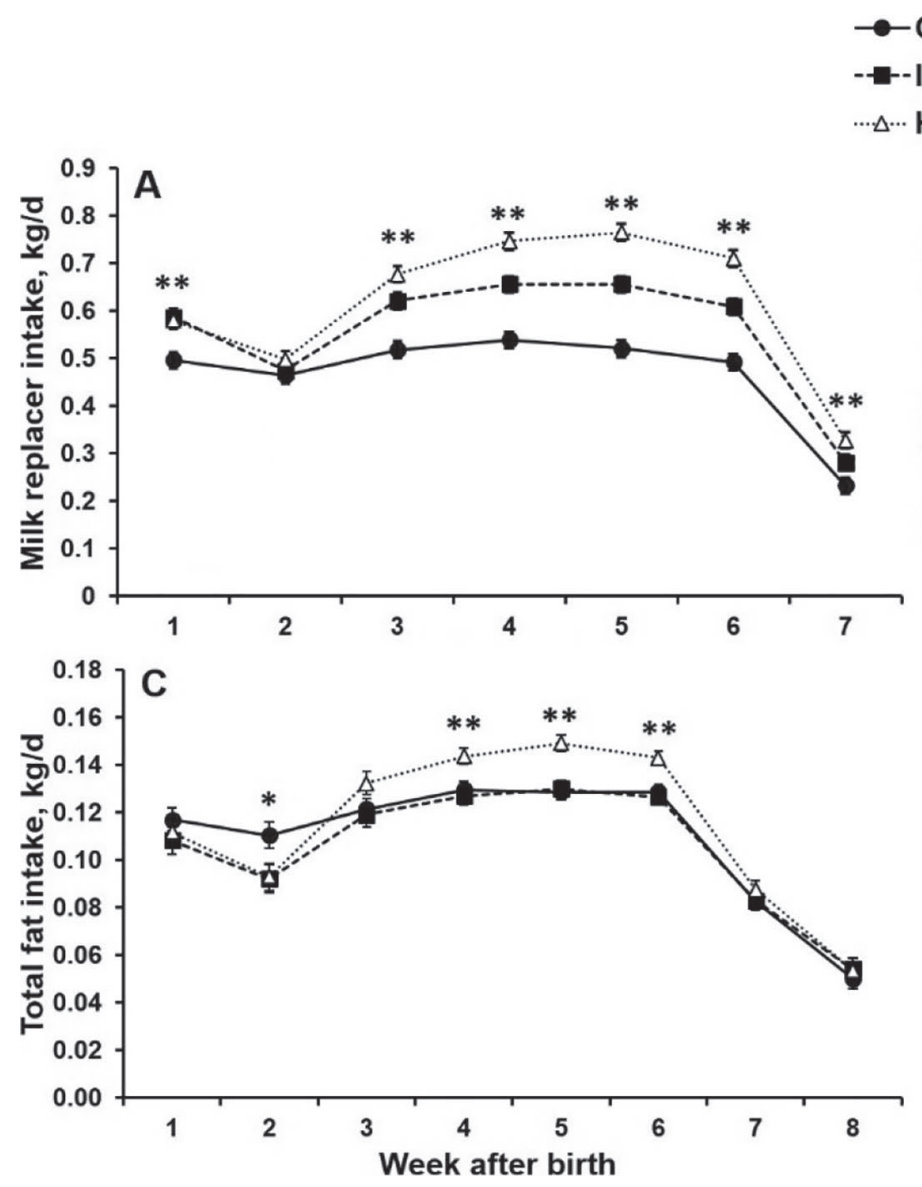

CON

-IL

‥ HL
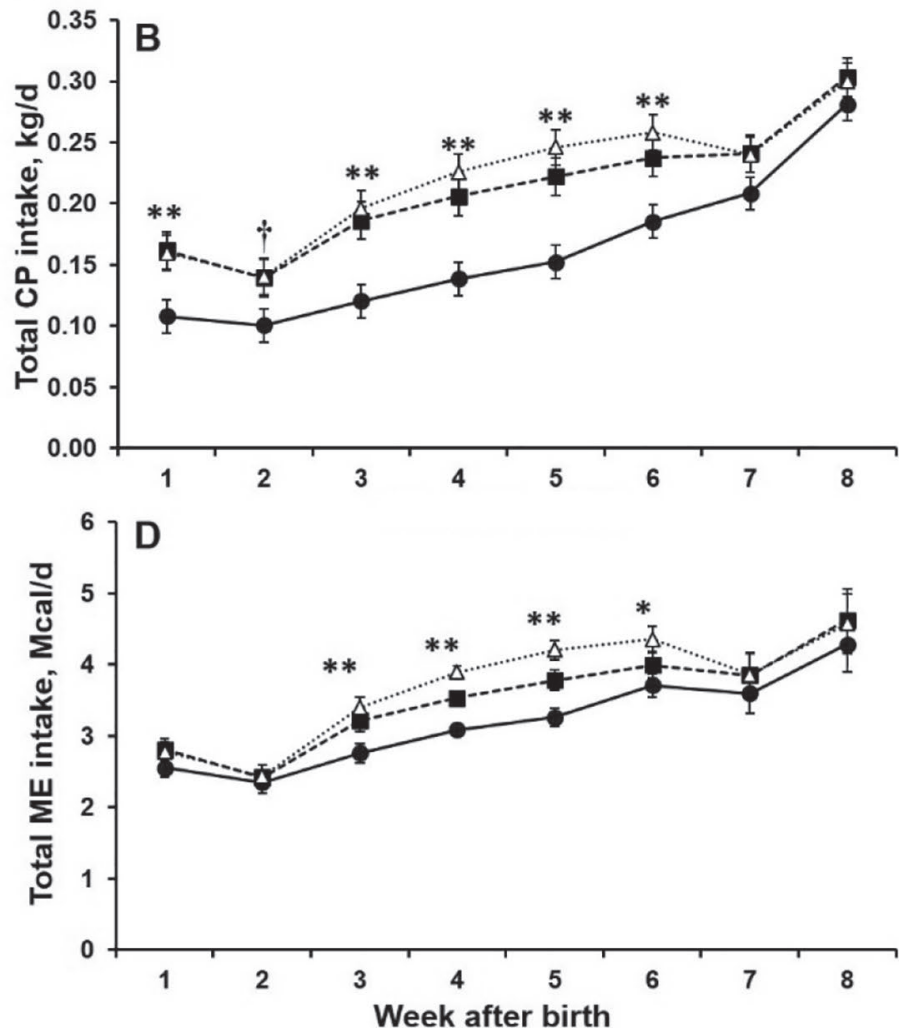

Figure 2. The intakes of milk replacer $(\mathrm{MR}), \mathrm{CP}$, fat, and $\mathrm{ME}$ of calves fed experimental diets starting at d 3 of age. CON $=0.55 \mathrm{~kg} \mathrm{DM}$ of a $20 \% \mathrm{CP}$ and $20 \%$ fat milk replacer per day; IL $=0.66 \mathrm{~kg} \mathrm{DM}$ of a $26 \% \mathrm{CP}$ and $17 \%$ fat milk replacer per day; $\mathrm{HL}=0.77 \mathrm{~kg} \mathrm{DM}$ of a $26 \%$ $\mathrm{CP}$ and $17 \%$ fat milk replacer per day. Error bars represent SEM. ${ }^{* *} P \leq 0.01,{ }^{*} P \leq 0.05, \dagger P \leq 0.10$.

$\times$ time interaction $(P=0.05)$ was observed for plasma urea nitrogen concentration, mainly due to the effect of time within each treatment because no differences were observed between treatments at each time points.

\section{DISCUSSION}

Calves were exposed to elevated ambient temperature and relative humidity throughout the current trial. The rectal temperature and respiration rate of calves averaged $39.6^{\circ} \mathrm{C}$ and 75 breath $/ \mathrm{min}$, respectively, which is above the normal body temperature $\left(38.5^{\circ} \mathrm{C}\right)$ of a calf under thermoneutral conditions (Collier et al., 2019) but did not differ among treatments. These data suggest that calves enrolled in this experiment experienced heat stress throughout the trial. Interestingly, the ambient temperature inside the hutch was 1.5 to $3.8^{\circ} \mathrm{C}$ higher than that outside from 1000 to $1800 \mathrm{~h}$ during the day. This suggests that the enclosed hutch accumulates heat during the hottest time of day and indicates a need for interventions to reduce heat accumulation. In a relatively dry environment (relative humidity ranges from 15 to $70 \%$ ), elevating the back of the hutches by $20 \mathrm{~cm}$ slightly reduced the internal ambient temperature of the hutch by $0.12^{\circ} \mathrm{C}$ compared with the external ambient temperature and decreased calf respiration rate in the afternoon (Moore et al., 2012). In the current study, the windows located in the back and on the ridge of the hutch were fully opened to improve ventilation, but the back of the hutches was not elevated. In a study by Spain and Spiers (1996), providing an 80\% solar radiation blockage shade cloth over plastic hutches reduced the temperature inside hutches by $2.3^{\circ} \mathrm{C}$ compared with hutches without shade (29.7 vs. $32.0^{\circ} \mathrm{C}$, respectively). Alternatively, the door of the hutches can be oriented to the east to maximize the shade area outside the hutches in the late afternoon, when the ambient temperature inside the hutches is higher than that outside.

The objective of this study was to investigate whether increasing the feeding rate of MR could improve growth 


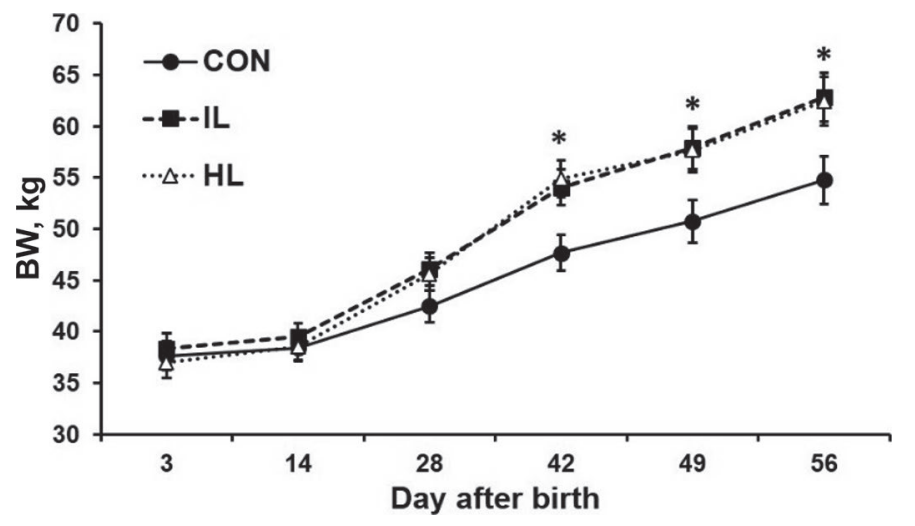

Figure 3. Body weight of calves fed experimental diets starting from d 3 of age. CON $=0.55 \mathrm{~kg} \mathrm{DM}$ of a $20 \% \mathrm{CP}$ and $20 \%$ fat milk replacer per day; IL $=0.66 \mathrm{~kg} \mathrm{DM}$ of a $26 \% \mathrm{CP}$ and $17 \%$ fat milk replacer per day; $\mathrm{HL}=0.77 \mathrm{~kg} \mathrm{DM}$ of a $26 \% \mathrm{CP}$ and $17 \%$ fat milk replacer per day. Error bars represent SEM. ${ }^{* *} P \leq 0.01,{ }^{*} P \leq 0.05$, $\dagger P \leq 0.10$.

of preweaned calves during summer heat stress. Three out of 12 calves enrolled in the AL treatment experienced abomasal bloating during the first $30 \mathrm{DOA}$, and 2 died (17\% mortality rate). No abomasal bloating was observed in calves fed the other treatments. The high incidence of abomasal bloating observed for $\mathrm{AL}$ was unexpected and inconsistent with previous reports. Using a similar MR product (26:17), no abomasal bloating was reported for calves fed $0.87 \mathrm{~kg} / \mathrm{d}$ or more twice daily in a temperate environment (average ambient temperature: $21^{\circ} \mathrm{C}$; Chapman et al., 2016; Hill et al., 2016b). This surprising finding suggests that feeding a large quantity of milk twice daily in an extreme heat stress environment, as is often observed during summer in the southeastern region of the United States, delays MR abomasal emptying rate, which resulted in excessive gas production and abomasal bloating (Burgstaller et al., 2017). Heat stress is known as a limiting factor for gastric motility in dairy cattle. Under summer or environment conditions characterized by elevated temperature, lactating dairy cows and prepubertal heifers have slower rate of passage (McDowell et al., 1969; Nonaka et al., 2008), which enhances nutrient digestibility but limits feed intake. The effect of heat stress on calf gastric motility and abomasal emptying has not been reported (Burgstaller et al., 2017). In addition to volume, osmolality of the milk influences abomasal emptying rate (Burgstaller et al., 2017). Elevation of osmolality of the milk by mixing with electrolytes

Table 4. Growth performance of calves fed experimental diets starting from $3 \mathrm{~d}$ of age ${ }^{1}$

\begin{tabular}{|c|c|c|c|c|c|c|c|}
\hline \multirow[b]{2}{*}{ Item } & \multicolumn{3}{|c|}{ Treatment $^{2}$} & \multirow[b]{2}{*}{ SEM } & \multicolumn{3}{|c|}{$P$-value } \\
\hline & $\mathrm{CON}$ & IL & HL & & Treatment & Time & $\begin{array}{l}\text { Treatment } \\
\times \text { time }\end{array}$ \\
\hline $\mathrm{BW}, \mathrm{kg}$ & 45.29 & 49.79 & 49.34 & 1.63 & 0.11 & $<0.01$ & $<0.01$ \\
\hline $\mathrm{ADG}, \mathrm{kg} / \mathrm{d}$ & $0.34^{\mathrm{a}}$ & $0.47^{\mathrm{b}}$ & $0.46^{\mathrm{b}}$ & 0.04 & 0.05 & $<0.01$ & 0.26 \\
\hline \multicolumn{8}{|l|}{$\mathrm{BW}$ gain, $\mathrm{kg}$} \\
\hline d $3-28$ & $4.81^{\mathrm{a}}$ & $7.71^{\mathrm{b}}$ & $8.68^{\mathrm{b}}$ & 0.84 & 0.01 & - & - \\
\hline d $28-56$ & $11.83^{\mathrm{a}}$ & $16.77^{\mathrm{b}}$ & $16.79^{\mathrm{b}}$ & 1.78 & 0.09 & - & - \\
\hline d $3-56$ & $16.57^{\mathrm{a}}$ & $24.46^{\mathrm{b}}$ & $25.49^{\mathrm{b}}$ & 2.12 & 0.01 & - & - \\
\hline \multicolumn{8}{|c|}{ Heart girth gain, $\mathrm{cm}$} \\
\hline d $3-28$ & $1.83^{\mathrm{a}}$ & $4.76^{\mathrm{b}}$ & $5.21^{\mathrm{b}}$ & 0.62 & $<0.01$ & - & - \\
\hline d $28-56$ & 6.89 & 7.59 & 8.14 & 0.94 & 0.64 & - & - \\
\hline d 3-56 & $8.65^{\mathrm{a}}$ & $12.36^{\mathrm{b}}$ & $13.36^{\mathrm{b}}$ & 1.12 & 0.01 & - & - \\
\hline \multicolumn{8}{|c|}{ Withers height gain, $\mathrm{cm}$} \\
\hline d $3-28$ & 3.32 & 3.27 & 3.70 & 0.48 & 0.80 & - & - \\
\hline d $28-56$ & $3.66^{\mathrm{a}}$ & $4.88^{\mathrm{b}}$ & $4.82^{\mathrm{b}}$ & 0.36 & 0.04 & - & - \\
\hline d 3-56 & 6.97 & 8.14 & 8.52 & 0.55 & 0.12 & - & - \\
\hline \multicolumn{8}{|c|}{ Hip height gain, cm } \\
\hline d $3-28$ & 3.01 & 2.77 & 3.54 & 0.46 & 0.49 & - & - \\
\hline d $28-56$ & $3.38^{\mathrm{a}}$ & $4.45^{\mathrm{ab}}$ & $5.10^{\mathrm{b}}$ & 0.42 & 0.02 & - & - \\
\hline d 3-56 & $6.30^{\mathrm{a}}$ & $7.22^{\mathrm{ab}}$ & $8.63^{\mathrm{b}}$ & 0.57 & 0.02 & - & - \\
\hline \multicolumn{8}{|c|}{ Body length gain, $\mathrm{cm}$} \\
\hline d $3-28$ & 3.64 & 4.51 & 4.39 & 0.57 & 0.50 & - & - \\
\hline d $28-56$ & 4.63 & 5.71 & 5.42 & 0.50 & 0.31 & - & - \\
\hline d 3-56 & $8.23^{\mathrm{a}}$ & $10.21^{\mathrm{b}}$ & $9.81^{\mathrm{ab}}$ & 0.60 & 0.06 & - & - \\
\hline
\end{tabular}

${ }_{\mathrm{a}, \mathrm{b}}$ Means within a row with different superscripts differ $(P \leq 0.05)$.

${ }^{1}$ All calves were housed in individual polyethylene hutches during the summer and fed twice daily. Measures were taken at d $3,14,28,42$, and 56 of age.

${ }^{2} \mathrm{CON}=0.55 \mathrm{~kg}$ DM of a $20 \% \mathrm{CP}$ and $20 \%$ fat milk replacer per day; $\mathrm{IL}=0.66 \mathrm{~kg}$ DM of a $26 \% \mathrm{CP}$ and $17 \%$ fat milk replacer per day; $\mathrm{HL}=0.77 \mathrm{~kg} \mathrm{DM}$ of a $26 \% \mathrm{CP}$ and $17 \%$ fat milk replacer per day. 
Table 5. Select plasma metabolites and insulin concentrations of calves fed experimental diets starting from d 3 of age ${ }^{1}$

\begin{tabular}{|c|c|c|c|c|c|c|c|}
\hline \multirow[b]{2}{*}{ Item } & \multicolumn{3}{|c|}{ Treatment $^{2}$} & \multirow[b]{2}{*}{ SEM } & \multicolumn{3}{|c|}{$P$-value } \\
\hline & $\mathrm{CON}$ & IL & HL & & Treatment & Time & $\begin{array}{l}\text { Treatment } \\
\times \text { time }\end{array}$ \\
\hline Insulin, $\mu \mathrm{g} / \mathrm{L}$ & $0.30^{\mathrm{a}}$ & $0.40^{\mathrm{b}}$ & $0.53^{\mathrm{c}}$ & 0.04 & $<0.01$ & $<0.01$ & 0.14 \\
\hline Nonesterified fatty acids, $\mu \mathrm{Eq} / \mathrm{L}$ & 183.7 & 177.7 & 180.0 & 7.0 & 0.83 & $<0.01$ & 0.63 \\
\hline $\mathrm{BHB}, \mathrm{mg} / \mathrm{dL}$ & 0.84 & 0.88 & 0.83 & 0.08 & 0.90 & $<0.01$ & 0.26 \\
\hline
\end{tabular}

${ }^{\mathrm{a}-\mathrm{c}}$ Means within a row with different superscripts differ $(P \leq 0.05)$.

${ }^{1}$ All calves were housed in individual polyethylene hutches during the summer and fed twice daily. Plasma was collected at d 5, 10, 14, 28, 42, $43,45,47,49,51$, and 56 of age.

${ }^{2} \mathrm{CON}=0.55 \mathrm{~kg} \mathrm{DM}$ of a $20 \% \mathrm{CP}$ and $20 \%$ fat milk replacer per day; IL $=0.66 \mathrm{~kg} \mathrm{DM}$ of a $26 \% \mathrm{CP}$ and $17 \%$ fat milk replacer per day; $\mathrm{HL}=$ $0.77 \mathrm{~kg} \mathrm{DM}$ of a $26 \% \mathrm{CP}$ and $17 \%$ fat milk replacer per day.

significantly delays the abomasum emptying rate (Constable et al., 2009). The osmolality of MR used in the current experiment was roughly estimated by adding the osmolality of the lactose and macrominerals and averaged 333.98 and $332.10 \mathrm{mOsm} / \mathrm{kg}$ for the $20: 20$ and 26:17 MR, respectively. The reasons for greater fecal score and increased incidence of scours of calves fed more milk relative to $\mathrm{CON}$ calves are unclear but may suggest a disturbance of digestion in calves fed large quantities of MR in the summer.

Among the 3 remaining treatments, MR intake reached the expected levels only after $4 \mathrm{wk}$ of age, especially for IL and HL calves. This observation contradicts previous studies conducted in temperate environments (Terré et al., 2006; Chapman et al., 2016; Hill et al., 2016b; MacPherson et al., 2016), which reported
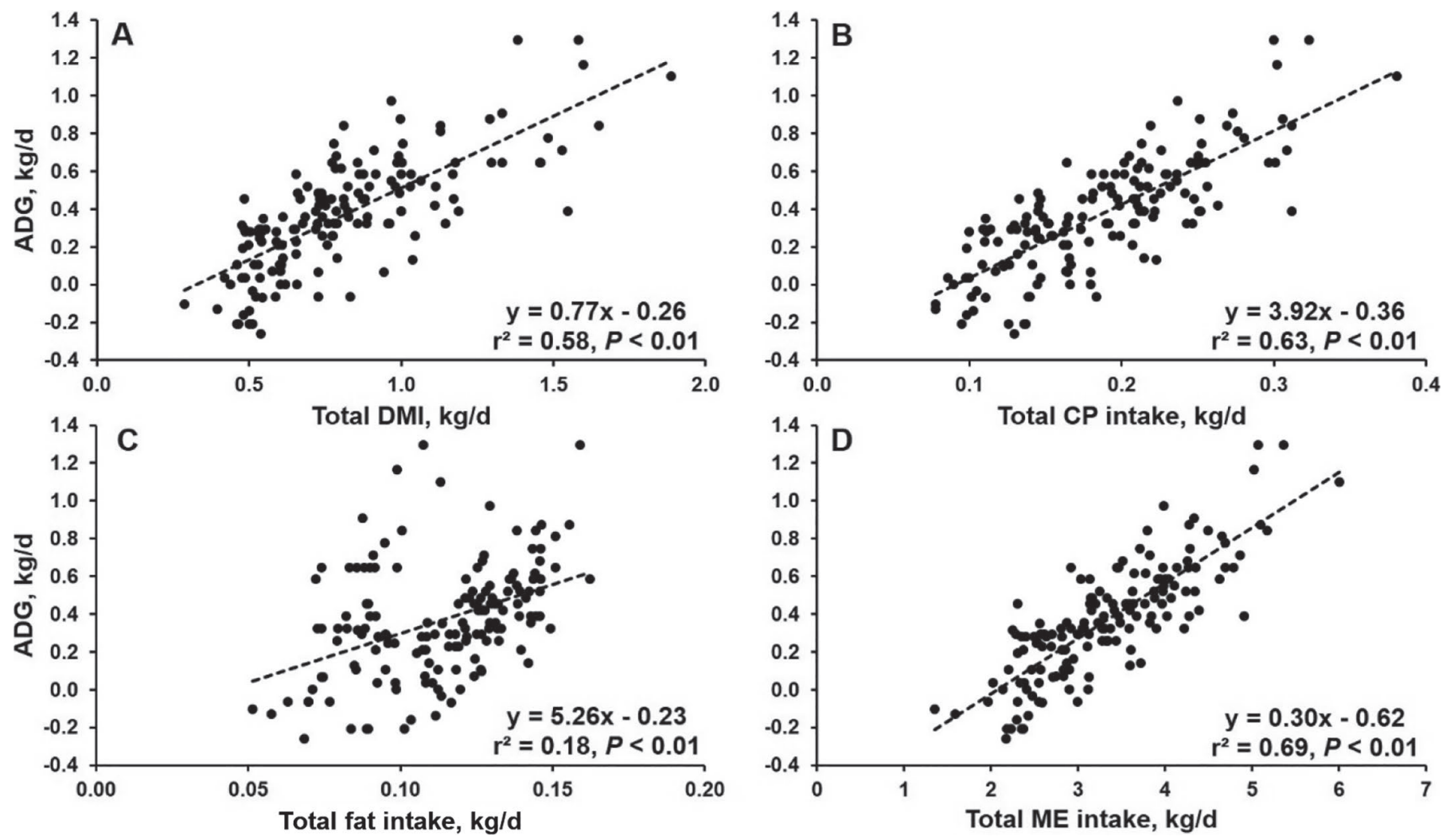

Figure 4. The correlation between ADG and the total intake of DM, CP, fat, and ME of calves from 3 to $49 \mathrm{~d}$ of age. 
that calves were able to consume large quantities of MR $(>0.77 \mathrm{~kg} / \mathrm{d})$ twice daily after wk 2 of age, suggesting that calves raised in heat stress conditions not only have reduced starter intake but may also have decreased MR intake when a large amount of MR is fed twice daily. The biological mechanism of the reduced MR intake is unknown but presumably attributed to the delayed gastric motility and abomasal emptying. In prepubertal heifers and adult cattle, heat stress reduces gastric motility, which inhibits DMI (McDowell et al., 1969; West, 2003; Nonaka et al., 2008). No treatment effect was observed for starter intake, which is contradictory to previous studies in which feeding more MR in a temperate environment reduced starter intake (Terré et al., 2006; Chapman et al., 2016; Hill et al., 2016b); however calves fed the HL diet did not consume as much MR as allotted.

Feeding accelerated MR (IL and HL) increased ADG and skeletal growth compared with feeding the CON diet, confirming the advantage of accelerated MR over conventional MR for improving growth performance (Khan et al., 2007). Although they consumed more MR and total ME, HL calves had similar ADG and gain in skeletal growth during the preweaning period relative to IL calves. Feeding large quantities of milk may impede nutrient digestibility of calf starter. The effect of milk feeding rate on apparent total-tract nutrient digestibility of calf starter in temperate environments was examined previously using either direct (total fecal collection; Terré et al., 2007) or indirect (indigestible marker; Chapman et al., 2016; Hill et al., 2016b) methods. Studies suggested that feeding large quantities of MR twice daily reduced digestibility of DM, OM, fat, $\mathrm{CP}$, and NDF provided by calf starter, primarily due to delayed rumen development as a result of lower starter intake (Terré et al., 2007; Chapman et al., 2016; Hill et al., 2016b). In the current study, no difference in starter intake was observed between calves fed HL and IL, and all calves had similar plasma levels of BHB during the entire experimental period, suggesting similar rumen development. Compared with preweaned calves fed $0.66 \mathrm{~kg} \mathrm{DM}$ of $26: 17 \mathrm{MR} / \mathrm{d}$, similar to the $\mathrm{MR}$ in the current study, calves fed $1.31 \mathrm{~kg}$ of $\mathrm{MR} / \mathrm{d}$ had higher digestibility of DM, OM, fat, and $\mathrm{CP}$ provided by MR at wk 3 of age (Hill et al., 2016b), indicating improved $\mathrm{MR}$ digestion. In veal calves, feeding $\mathrm{MR}$ at $2.5 \times \mathrm{ME}$ for maintenance $\left(\mathbf{M E}_{\mathbf{m}}\right)$ resulted in similar MR nutrient digestibility as in calves fed MR at $1.5 \times \mathrm{ME}_{\mathrm{m}}$ (van den Borne et al., 2006). Therefore, it is unlikely that the altered nutrient digestibility of MR or calf starter is the reason for the discordance between MR intake and ADG observed in the current study. However, future research is needed to examine the effect of MR feeding rate on digestibility of nutrients provided by MR and calf starter during summer.

Relative to veal calves fed $\mathrm{MR}$ at $1.5 \times \mathrm{ME}_{\mathrm{m}}$, increasing the feeding rate to $2.5 \times \mathrm{ME}_{\mathrm{m}}$ increased heat production from the oxidation of AA and carbohydrates on the BW basis, suggesting increased energy loss and lower nutrient utilization for growth (van den Borne et al., 2006, 2007). The inefficient utilization of energy and nutrients by feeding more MR may be due to gastrointestinal hypertrophy to cope with the large meal sizes and delayed abomasal emptying (MacPherson et al., 2016) and to the increase in temporal plasma AA concentrations that exceed the requirement for protein retention, resulting in AA oxidation (van den Borne et al., 2006, 2007). Delayed abomasal emptying may also increase abomasal fermentation of nutrients, especially carbohydrates (Burgstaller et al., 2017). These will result in a net loss of energy and nutrients before absorption in the small intestine. Thus, it seems that large meal size and delayed abomasal emptying are potential mechanisms limiting nutrient utilization of calves fed large quantities of milk with limited feeding frequency (e.g., twice daily). Under a temperate environment and normal gastric functions, calf abomasal emptying will be delayed to a certain extent when feeding a large quantity of milk per meal (MacPherson et al., 2016). Delayed abomasal empting is considered a mechanism to regulate large influxes of nutrients into the small intestine and has minimal effect on animal growth (van den Borne et al., 2006; MacPherson et al., 2016). However, during summer, abomasal emptying may be further delayed by heat stress, which may exaggerate the loss of energy and nutrients, causing lower growth.

In addition to energy and nutrient utilization, MR feeding rate and frequency influence calf growth through altered glucose metabolism. In veal calves, long-term feeding with large quantities of MR twice daily is related to hyperglycemia, hyperinsulinemia, and insulin resistance in peripheral tissues (Doppenberg and Palmquist, 1991; Hostettler-Allen et al., 1994). The reduced insulin sensitivity results from lessabundant insulin receptors on peripheral tissues due to a negative feedback mechanism of prolonged elevation of plasma insulin (Hugi et al., 1998). In dairy calves, studies reported that increasing the MR feeding rate increased the insulin response after a glucose tolerance test but did not alter the glucose clearance of a preweaned calf (Bach et al., 2013; Yunta et al., 2015; MacPherson et al., 2016). Similarly, we observed that plasma glucose concentration was not influenced by MR intake during summer but that insulin concentration was increased as the feeding rate increased $(\mathrm{CON}<\mathrm{IL}$ $<\mathrm{HL}$ ). These data indicate that feeding large quanti- 
ties of MR increases pancreatic sensitivity to release insulin and possibly results in reduced insulin action on peripheral tissues (e.g., muscle and adipose tissue; Bach et al., 2013; Yunta et al., 2015; MacPherson et al., 2016). Heat stress may also influence glucose and insulin metabolism of the calf. Previous studies (Tao et al., 2014; Monteiro et al., 2016) observed that maternal heat stress during the last $45 \mathrm{~d}$ of gestation increased glucose clearance after glucose tolerance test of the preweaned calf without enhancing insulin sensitivity on peripheral tissues (Monteiro et al., 2016), suggesting an increase in glucose utilization by insulin-independent tissues. Therefore, animals raised under heat stress conditions may have lower efficiency of glucose utilization for growth, which may be exaggerated by feeding large amounts of milk.

In temperate environments, increasing MR feeding frequency from twice to 3 or 4 times daily improves calf growth before weaning (van den Borne et al., 2006, 2007; Sockett et al., 2011; MacPherson et al., 2016). Further, increasing MR feeding frequency has been proven to accelerate abomasal emptying (MacPherson et al., 2016), improve energy and nutrient utilization (van den Borne et al., 2006, 2007), and potentially alter glucose partitioning toward peripheral tissues in preweaned calves (MacPherson, 2016). Therefore, more frequent feeding may be implemented when a large quantity of MR is fed during summer to overcome the potential limitation of delayed abomasal emptying, losses of energy and nutrients, and glucose metabolism altered by large meal size and heat stress. Related studies are not available but deserve further investigation.

In addition to increased MR allowance to increase the energy intake of a calf during summer, the other strategy is to increase the fat content of MR. A previous study (van den Borne et al., 2007) indicated that preruminant calves require glucose as a fuel rather than fat, which is primarily deposited into adipose tissue. In the current study, regardless of treatment, the ADG of calves from 3 to 49 DOA had the lowest correlation with total fat intake compared with total intake of DMI, CP, and ME. Calves fed the CON diet ingested similar amounts of fat relative to calves fed the IL diet but had lower ADG, further indicating that increasing MR fat content may have minimal effect on calf growth during summer. The ADG of calves had the highest correlation with total ME intake, suggesting the importance of increasing energy intake for increased ADG during summer. This, however, may not be achieved by increasing the MR fat content.

It is important to recognize that postnatal heat stress is not the only environmental cue that influences calf performance during summer. Previous studies (Monteiro et al., 2016; Laporta et al., 2017) indicated that maternal heat stress during the dry period negatively influenced growth performance of the calves and affected glucose metabolism during the preweaning period. In the current study, calves were balanced by calving date before enrolling into the treatments, but the possibility that there was an interaction between maternal heat stress and postnatal nutritional management on calf growth cannot be excluded and deserves further investigation. Additionally, the long day photoperiod has positive effects on starter intake and ADG before weaning relative to the short day photoperiod (Osborne et al., 2007). However, the longer day length during summer cannot override the negative effect of heat stress on calf growth because of a lower ADG observed during summer (Wiedmeier et al., 2006; Broucek et al., 2009).

\section{CONCLUSIONS}

During summer, calves experience reduced growth partially due to altered energy metabolism and reduced starter intake because of heat stress. The result of the current study indicated that feeding an accelerated $26: 17 \mathrm{MR}$ at $0.66 \mathrm{~kg}$ of $\mathrm{DM} / \mathrm{d}$ twice daily improved growth compared with feeding a conventional 20:20 MR at $0.55 \mathrm{~kg}$ of $\mathrm{DM} / \mathrm{d}$ during summer. However, increasing the MR allowance to $0.77 \mathrm{~kg}$ of $\mathrm{DM} / \mathrm{d}$ failed to improve growth further, and higher levels of MR feeding were related to increased incidence of abomasal bloating. These results suggest that feeding large quantities of MR with limited frequency during summer may be associated with delayed abomasal emptying rate due to large meal size and heat stress, which prevents effective energy utilization for growth. Future research needs to focus on approaches (i.e., increased feeding frequency) that could accelerate abomasal emptying and increase energy utilization of the calves when feeding a large quantity of MR during summer.

\section{ACKNOWLEDGMENTS}

The authors thank the staff of the Dairy Research Center and the Department of Animal and Dairy Science of the University of Georgia-Tifton campus for animal care, data collection, and sample analysis. The authors also extend their appreciation to Milk Checkoff funded by Southeast Milk Inc. (Belleview, FL) and NIFA (Washington, DC) Hatch project (GEO00749) for partial funding support.

\section{REFERENCES}

Bach, A., L. Domingo, C. Montoro, and M. Terré. 2013. Short communication: Insulin responsiveness is affected by the level of milk 
replacer offered to young calves. J. Dairy Sci. 96:4634-4637. https: //doi.org/10.3168/jds.2012-6196.

Ballou, M. A., D. L. Hanson, C. J. Cobb, B. S. Obeidat, M. D. Sellers, A. R. Pepper-Yowell, J. A. Carroll, T. J. Earleywine, and S. D. Lawhon. 2015. Plane of nutrition influences the performance, innate leukocyte responses, and resistance to an oral Salmonella enterica serotype Typhimurium challenge in Jersey calves. J. Dairy Sci. 98:1972-1982. https://doi.org/10.3168/jds.2014-8783.

Broucek, J., P. Kisac, and M. Uhrincat. 2009. Effect of hot temperatures on the hematological parameters, health and performance of calves. Int. J. Biometeorol. 53:201-208. https://doi.org/10.1007/ s00484-008-0204-1.

Burgstaller, J., T. Wittek, and G. W. Smith. 2017. Invited review: Abomasal emptying in calves and its potential influence on gastrointestinal disease. J. Dairy Sci. 100:17-35. https://doi.org/10 $.3168 /$ jds.2016-10949.

Chapman, C. E., P. S. Erickson, J. D. Quigley, T. M. Hill, H. G. Bateman, F. X. Suarez-Mena, and R. L. Schlotterbeck. 2016. Effect of milk replacer program on calf performance and digestion of nutrients with age of the dairy calf. J. Dairy Sci. 99:2740-2747. https:/ /doi.org/10.3168/jds.2015-10372.

Chavez, T. M. 2011. Adjusting milk replacer intake during heat stress and non-heat stress as a means of improving dairy calf performance. MS Thesis. Texas A\&M University, College Station, TX.

Collier, R. J., L. H. Baumgard, R. B. Zimbelman, and Y. Xiao. 2019. Heat stress: Physiology of acclimation and adaptation. Anim. Front. 9:12-19. https://doi.org/10.1093/af/vfy031.

Constable, P. D., W. Grünberg, and L. Carstensen. 2009. Comparative effects of two oral rehydration solutions on milk clotting, abomasal luminal $\mathrm{pH}$, and abomasal emptying rate in sucking calves. J. Dairy Sci. 92:296-312. https://doi.org/10.3168/jds.2008-1462.

Doppenberg, J., and D. L. Palmquist. 1991. Effect of dietary fat level on feed intake, growth, plasma metabolites and hormones of calves fed dry or liquid diets. Livest. Prod. Sci. 29:151-166. https://doi .org/10.1016/0301-6226(91)90063-V.

Gebremedhin, K. G., C. O. Cramer, and W. P. Porter. 1981. Predictions and measurement of heat production and food and water requirements of Holstein calves in different environments. Trans. ASAE 24:715-720. https://doi.org/10.13031/2013.34326.

Hill, T. M., H. G. Bateman, J. M. Aldrich, and R. L. Schlotterbeck. 2011. Comparisons of housing, bedding, and cooling options for dairy calves. J. Dairy Sci. 94:2138-2146. https://doi.org/10.3168/ jds.2010-3841.

Hill, T. M., H. G. Bateman, J. M. Aldrich, and R. L. Schlotterbeck. 2012. Case study: Effect of feeding rate and weaning age of dairy calves fed a conventional milk replacer during warm summer months. Prof. Anim. Sci. 28:125-130. https://doi.org/10.15232/ S1080-7446(15)30324-7.

Hill, T. M., H. G. Bateman, F. X. Suarez-Mena, T. S. Dennis, and R. L. Schlotterbeck. 2016a. Short communication: Changes in body temperature of calves up to 2 months of age as affected by time of day, age, and ambient temperature. J. Dairy Sci. 99:8867-8870. https://doi.org/10.3168/jds.2016-10994.

Hill, T. M., J. D. Quigley, F. X. Suarez-Mena, H. G. Bateman, and R. L. Schlotterbeck. 2016b. Effect of milk replacer feeding rate and functional fatty acids on dairy calf performance and digestion of nutrients. J. Dairy Sci. 99:6352-6361. https://doi.org/10.3168/jds .2015-10812.

Hostettler-Allen, R. L., L. Tappy, and J. W. Blum. 1994. Insulin resistance, hyperglycemia, and glucosuria in intensively milk-fed calves. J. Anim. Sci. 72:160-173. https://doi.org/10.2527/1994.721160x.

Hugi, D., L. Tappy, H. Sauerwein, R. M. Bruckmaier, and J. W. Blum. 1998. Insulin-dependent glucose utilization in intensively milk-fed veal calves is modulated by supplemental lactose in an age-dependent manner. J. Nutr. 128:1023-1030. https://doi.org/10.1093/jn/ 128.6.1023.

Khan, M. A., H. J. Lee, W. S. Lee, H. S. Kim, S. B. Kim, K. S. Ki, J. K. Ha, H. G. Lee, and Y. J. Choi. 2007. Pre- and postweaning performance of Holstein female calves fed milk through step-down and conventional methods. J. Dairy Sci. 90:876-885. https://doi .org/10.3168/jds.S0022-0302(07)71571-0.
Laporta, J., T. F. Fabris, A. L. Skibiel, J. L. Powell, M. J. Hayen, K. Horvath, E. K. Miller-Cushon, and G. E. Dahl. 2017. In utero exposure to heat stress during late gestation has prolonged effects on the activity patterns and growth of dairy calves. J. Dairy Sci. 100:2976-2984. https://doi.org/10.3168/jds.2016-11993.

MacPherson, J. A. R. 2016. Effects of pre-weaning plane of milk replacer and feeding frequency on glucose metabolism in dairy calves. MS Thesis. University of Alberta, Edmonton, AB, Canada.

MacPherson, J. A. R., H. Berends, L. N. Leal, J. P. Cant, J. MartinTereso, and M. A. Steele. 2016. Effect of plane of milk replacer intake and age on glucose and insulin kinetics and abomasal emptying in female Holstein Friesian dairy calves fed twice daily. J. Dairy Sci. 99:8007-8017. https://doi.org/10.3168/jds.2015-10826.

McDowell, R. E., E. G. Moody, P. J. Vansoest, R. P. Lehmann, and G. L. Ford. 1969. Effect of heat stress on energy and water utilization of lactating cows. J. Dairy Sci. 52:188-194. https://doi.org/10 .3168/jds.S0022-0302(69)86528-8.

Monteiro, A. P. A., J.-R. Guo, X.-S. Weng, B. M. Ahmed, M. J. Hayen, G. E. Dahl, J. K. Bernard, and S. Tao. 2016. Effect of maternal heat stress during the dry period on growth and metabolism of calves. J. Dairy Sci. 99:3896-3907. https://doi.org/10.3168/jds 2015-10699.

Moore, D. A., J. L. Duprau, and J. R. Wenz. 2012. Short communication: Effects of dairy calf hutch elevation on heat reduction, carbon dioxide concentration, air circulation, and respiratory rates. J. Dairy Sci. 95:4050-4054. https://doi.org/10.3168/jds.2012-5397.

Nonaka, I., N. Takusari, K. Tajima, T. Suzuki, K. Higuchi, and M. Kurihara. 2008. Effects of high environmental temperatures on physiological and nutritional status of prepubertal Holstein heifers. Livest. Sci. 113:14-23. https://doi.org/10.1016/j.livsci.2007.02 .010 .

NRC. 2001. Nutrient Requirements of Dairy Cattle. 7th rev. ed. Natl. Acad. Press, Washington, DC.

Obeidat, B. S., C. J. Cobb, M. D. Sellers, A. R. Pepper-Yowell, T. J. Earleywine, and M. A. Ballou. 2013. Plane of nutrition during the preweaning period but not the grower phase influences the neutrophil activity of Holstein calves. J. Dairy Sci. 96:7155-7166. https:/ /doi.org/10.3168/jds.2013-6699.

Osborne, V. R., N. E. Odongo, A. M. Edwards, and B. W. McBride. 2007. Effects of photoperiod and glucose-supplemented drinking water on the performance of dairy calves. J. Dairy Sci. 90:51995207. https://doi.org/10.3168/jds.2007-0402.

School of Veterinary Medicine, University of Wisconsin-Madison. 2011. Calf health scoring chart and calf health scoring criteria. Calves. Accessed May 2, 2016. http://www.vetmed.wisc.edu/dms/ fapm/fapmtools/8calf/calf_health_scoring_chart.pdf.

Sharon, K. P., Y. Liang, N. C. B. Sanchez, J. A. Carrol, P. R. Broadway, E. M. Davis, and M. A. Ballou. 2019. Pre-weaning plane of nutrition and Mannheimia haemolytica dose influence inflammatory responses to a bovine herpesvirus-1 and Mannheimia haemolytica challenge in post-weaning Holstein calves. J. Dairy Sci. 102:9082-9096. https://doi.org/10.3168/jds.2018-15997.

Soberon, F., E. Raffrenato, R. W. Everett, and M. E. Van Amburgh. 2012. Preweaning milk replacer intake and effects on long-term productivity of dairy calves. J. Dairy Sci. 95:783-793. https://doi .org/10.3168/jds.2011-4391.

Sockett, D. C., C. E. Sorenson, N. K. Betzold, J. T. Meronek, and T. J. Earleywine. 2011. Impact of three times versus twice a day milk replacer feeding on calf performance, likelihood to reach lactation and future milk production in a commercial dairy herd. J. Dairy Sci. 94(Suppl. 2):264. (Abstr.)

Spain, J. N., and D. E. Spiers. 1996. Effects of supplemental shade on thermoregulatory response of calves to heat challenge in a hutch environment. J. Dairy Sci. 79:639-646. https://doi.org/10.3168/ jds.S0022-0302(96)76409-3.

Tao, S., A. P. A. Monteiro, M. J. Hayen, and G. E. Dahl. 2014. Maternal heat stress during the dry period alters postnatal whole-body insulin response of calves. J. Dairy Sci. 97:897-901. https://doi .org/10.3168/jds.2013-7323.

Terré, M., M. Devant, and A. Bach. 2006. Performance and nitrogen metabolism of calves fed conventionally or following an enhanced- 
growth feeding program during the preweaning period. Livest. Sci. 105:109-119. https://doi.org/10.1016/j.livsci.2006.05.001.

Terré, M., M. Devant, and A. Bach. 2007. Effect of level of milk replacer fed to Holstein calves on performance during the preweaning period and starter digestibility at weaning. Livest. Sci. 110:82-88. https://doi.org/10.1016/j.livsci.2006.10.001.

USDA-National Animal Health Monitoring System. 2016. Dairy 2014: Dairy Cattle Management Practices in the United States, 2014 USDA-NAHMS, Fort Collins, CO.

van den Borne, J. J. G. C., G. E. Lobley, M. W. A. Verstegen, J. M. Muijlaert, S. J. J. Alferink, and W. J. J. Gerrits. 2007. Body fat deposition does not originate from carbohydrates in milk-fed calves. J. Nutr. 137:2234-2241. https://doi.org/10.1093/jn/137.10 .2234 .

van den Borne, J. J. G. C., M. W. A. Verstegen, S. J. J. Alferink, R. M. M. Giebels, and W. J. J. Gerrits. 2006. Effects of feeding frequency and feeding level on nutrient utilization in heavy prerumi- nant calves. J. Dairy Sci. 89:3578-3586. https://doi.org/10.3168/ jds.S0022-0302(06)72397-9.

West, J. W. 2003. Effects of heat-stress on production in dairy cattle. J. Dairy Sci. 86:2131-2144. https://doi.org/10.3168/jds.S0022 -0302(03)73803-X.

Wiedmeier, R. D., A. J. Young, and P. R. Schmidt. 2006. Watch the drinking water quality of calves reared in individual hutches. Assessed Nov. 5, 2015. http://digitalcommons.usu.edu/extension curall/1412/.

Wilms, J., H. Berends, and J. Martin-Tereso. 2019. Hypertonic milk replacers increase gastrointestinal permeability in healthy dairy calves. J. Dairy Sci. 102:1237-1246. https://doi.org/10.3168/jds .2018-15265.

Yunta, C., M. Terre, and A. Bach. 2015. Short- and medium-term changes in performance and metabolism of dairy calves offered different amounts of milk replacers. Livest. Sci. 181:249-255. https: /doi.org/10.1016/j.livsci.2015.09.008. 